\title{
Coulisses
}

Revue de théâtre

2 | Automne 1990

Spécial Festival des idées : Besançon ville ouverte aux jeunes

\section{Soirée Jeu théâtral}

Un comique pas toujours prémédité

\section{Rédaction}

\section{OpenEdition}

\section{Journals}

Édition électronique

URL : http://journals.openedition.org/coulisses/1592

DOI : $10.4000 /$ coulisses. 1592

ISSN : 2546-9460

\section{Éditeur}

Presses universitaires de Franche-Comté

\section{Édition imprimée}

Date de publication : 1 novembre 1990

Pagination : np

ISSN : 1150-594X

Référence électronique

Rédaction, « Soirée Jeu théâtral », Coulisses [En ligne], 2 | Automne 1990, mis en ligne le 04 juillet 2017, consulté le 21 octobre 2019. URL : http://journals.openedition.org/coulisses/1592 ; DOI : 10.4000/

coulisses. 1592

Ce document a été généré automatiquement le 21 octobre 2019

Coulisses 


\section{Soirée Jeu théâtral}

Un comique pas toujours prémédité

\section{Rédaction}

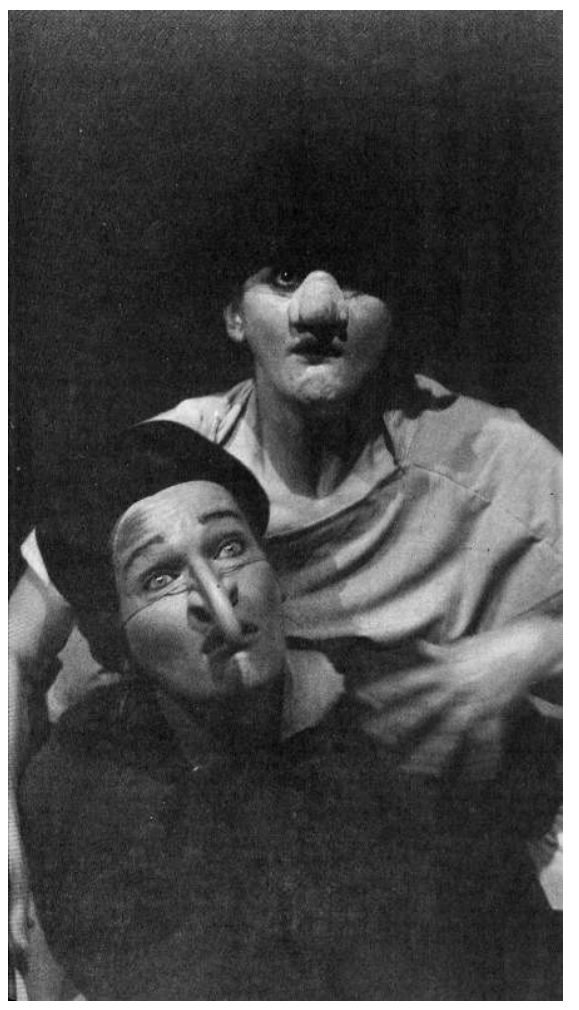

(c) Collectif Photo BVOJ 90.

1 Cinq ateliers théâtraux de Besançon et des environs se sont confrontés à partir de deux textes originaux écrits spécialement pour l'occasion par deux auteurs de la région, Madeleine Laude et Jean-Pierre Govignaux.

2 Nous n'avons vu que la première partie : à partir du même texte, drôle, on est pas des bêtes, chaque troupe jouait avec une mise en scène différente. Le premier intérêt du spectacle résidait dans cette approche différente de la pièce, où le décor et le jeu de 
chacun n'étaient pas figés; ce qui nous permettait, tout en connaissant le texte et le déroulement de la scène, de les redécouvrir à chaque fois.

3 Les troupes étaient issues d'ateliers amateurs : composés de jeunes et de moins jeunes, qui, pour la plupart n'avaient que peu ou pas de représentations à leur actif. On a donc $\mathrm{pu}$ voir et entendre des acteurs qui se trompaient, laissaient passer des blancs, ou laissant échapper un «zut » retentissant au beau milieu de leurs tirades. Ce qui aurait été condamnable dans un cadre plus austère, apportait ici un comique supplémentaire, sans préméditation aucune, et nous rendait très proches des acteurs. Entre chaque représentation, deux messieurs: Loyal et Dictionnaire, accompagnés d'un pseudo huissier, nous faisaient encore rire, en donnant des indications plus que farfelues qui devaient - en théorie - nous permettre de répondre à un questionnaire, tout-à-fait sérieux celui-là relatif au théâtre en général.

4 En résumé, c'était là une soirée gaie et décontractée, mais attention : un public moins indulgent aurait pu se lasser, rapidement, de ces erreurs répétées sur scène. 